\title{
Spill levende - bruk av dans og drama i fag
}

\section{Anette Sture Iversen}

ike før jul fikk organisasjonene på Seilet - huset

for kunst og kultur i skolen et felles oppdrag fra Utdanningsdirektoratet om å utvikle læringsressurser for bruk av praktiske og estetiske fag og arbeidsmåter i grunnopplæringen. Da det var tre ressurser som skulle utvikles og vi er seks fagorganisasjoner på Seilet, koblet vi ulike fag sammen i utviklingen av ressursene.

Jeg (på vegne av SANS) og Betine Johannessen (på vegne av Drama- og teaterpedagogene) utviklet sammen ressursen Spill levende - iscenesettelse av fortellinger fra fortid og samtid. Ressursen fremmer alternative metoder i arbeid med fortellinger - både faktiske og fiktive - som vi finner i mange av skolens fag, deriblant KRLE, norsk og samfunnsfag.

I mange fag i skolen inngår arbeid med tekst, historier og fortellinger, og flere kompetansemål omfatter å utforske, uttrykke, formidle og presentere tekstopplevelser. Utforske og presentere tekster behøver ikke å skje utelukkende ved å lese eller fremføre muntlig. I intervjuet med Annette Brandanger (dansekunstner og styreleder i SANS) som vi har laget i forbindelse med ressursen, forteller hun om hvordan elever fikk større interesse for en historisk hendelse i et fag etter at de hadde «gjennomlevd» fortellingen med kroppene sine og kunne relatere seg til tema på en mye sterkere måte og med hele seg. Dette med «hele seg» er viktig og omfatter mer enn en kognitiv forståelse eller tilknytning, for eksempel en kroppslig/fysisk og emosjonell tilknytning.

Ressursen Spill levende beskriver noen hovedkomponenter i arbeid med dans og drama og gir eksempler på øvelser innen hver komponent. Komponentene vi har fremhevet, er rolle, kropp, stemme og relasjoner. Ressursen knytter også opp til kompetansemål i KRLE, norsk, samfunnsfag og naturfag for å vise hvordan den kan forankres i det enkelte fag. Arbeidet knyttes også til overordnet del.

Dans og drama har mange fellesnevnere, men også noen ulikheter. Dans er et scenisk fag og innebærer gjerne iscenesettelse og elementer av fremvisning i en prosess, mens en innen drama, til forskjell fra teater, ikke er så opptatt av det. I dansen er kroppen og kroppsliggjøringen vesentlig, men vi måtte gi etter for Drama- og teaterpedagogene når det gjaldt å bruke begrepet kroppsliggjøring i tittelen på ressursen.

Vi håper at ressursen vi har utviklet kan bidra til at lærere i større grad tar i bruk metoder fra dans og drama $\mathrm{i}$ arbeid med tekst og fortellinger i ulike fag og sammenhenger i skolen. Vi tror at disse metodene kan bidra til dybdelæring, samarbeid og skaperglede hos elevene ved å gi gode opplevelser og rom for undring og refleksjon.

Les mer:

https://www.seiletressurs.no/ressursbasel spillevende. 